\title{
Does Diversity Matter for Religious Firms Too? Board Gender Diversity and Corporate Choices of Sharī‘ah Compliant Firms
}

\author{
Syed Danial Hashmi ${ }^{1 *}$, Saqib Gulzar ${ }^{2}$ \\ 1,2 Department of Management Sciences, COMSATS University, Islamabad, Wah Campus
}

\section{Keywords}

Board Gender Diversity Sharī'ah Compliant Firms KMI-30

Received: 06 May 2020

Accepted: 19 June 2020

\begin{abstract}
Governance mechanisms of religion-adhering firms offer a great debate topic in contemporary business and finance research. Though at nascent stages, yet there exists a growing body of knowledge regarding Islamic corporate finance. With an emphasis on this body of knowledge, the current study aims at examining the relationship between gender diversity in corporate sector boards on corporate choices of Sharī'ah compliant firms. Specifically, this study examines whether gender diverse boards of Sharī'ah compliant firms have any influence towards business diversification, dividend pay-out, and firm's financial performance or not? Study used data from Karachi-Meezan Index (KMI-30) of Shari`‘ahcompliant firms and employed panel data analysis technique. Results of the study show that gender diversity does matter for Sharī'ah compliant firms too. Representation of women on boards of Sharī'ah compliant firms results in more business diversification, dividend pay-out and better financial performance. The results are robust and carry crucial implications for policy makers of the Sharī'ah compliant firms, regulators and the government. Results of the study suggest that efforts should be deliberated to enhance women's inclusion in boards of Sharī'ah compliant firms. Our results must be interpreted with caution as they only relate to a specific type of stocks i.e. Islamic stocks and specific country i.e. an Islamic Republic of Pakistan.
\end{abstract}

KAUJIE Classification: T4, L43

JEL Classification: J16, L25, O16, Z12

(C) 2020 JIBM. All rights reserved.

\section{INTRODUCTION}

In empirical research on corporate finance, focus of researchers has recently shifted towards the examination of relationship between board gender diversity and strategic corporate

\footnotetext{
*Corresponding author: Syed Danial Hashmi

†Email: danialhashmi123@outlook.com
} 
choices. One stream of such research has examined relationship between gender diversity on board and performance of firm including both financial performance (Campbell \& MinguezVera, 2008; Erhardt, Werbel, \& Shrader, 2003; Siciliano, 1996) and social performance of the firm (Alazzani, Hassanein, \& Al-Janadi, 2017; Alazzani, Wan-Hussain, \& Jones, 2019; Shaukat, Qiu, \& Trojanowski, 2016; Rao \& Tilt, 2014). Despite high volume of research in this area, researchers have yet to reach any consensus regarding the direction of the relationship. Researchers have suggested that the inconclusiveness of the results is because of the difference in countries used for data analyses (Byron \& Post, 2016; Campbell \& Minguez-Vera, 2008).

Similarly, board gender diversity has been found to be associated with corporate sustainability (Galbreath, 2011), risk aversion and better decision making (Bernile, Bhagwat, \& Yonker, 2017). Studies have also shown that stock prices of firm with diverse board reflect more information than those who don't have a diverse board (Gul, Srinidhi, \& Ng, 2011). Despite the recent studies on board gender diversity and different corporate decisions, the research is still at nascent stage and researchers are calling for more research on the area.

The Upper Echelon theory (Hambrick \& Mason, 1984) provides framework for the relationship between board gender diversity and corporate choices. Theory argues that organizational choices are the reflections of cognitive bases and values of the top management team. One of the basic premises of the theory is that corporate choices are dependent on personal values of decision makers. Though gender was not identified as an important characteristic in initial upper echelon framework, a recent consensus has been developed among researchers that gender is an important variable which influences values and decision-making processes of top managers (Parola, Ellis, \& Golden, 2015). Upper echelon perspective has also been found to be consistent in explaining board gender diversity (Byron \& Post, 2016; Post \& Byron, 2015).

Religion is an important characteristic that influences one's values and perceptions and ultimately the decision making. Religious values of board can have an influence on corporate decision making (Alazzani \& Wan-Hussain, 2019). One of the most dominant religions in world is Islam and the concept of Islamic finance is widely evolving. Firms adhering to the tenets of Islam (called as Sharī'ah) are collectively termed as Sharī'ahcompliant firms. Though there is a consistent increase in research on Sharī'ah compliant firms, the central issue that remains concerning to these firms is the reliance of researchers on Shari'a ah indexes. The problem is that merely fetching inferences from Shari' 'ah indexes doesn't allow measuring the distinctness of Sharī ah principles in corporate decision making (Hooy \& Ali, 2017). Firm level research on Sharī'ahcompliant firms has remained focused on financial management practices of these firms. There is lack of empirical research that examines managerial attributes in relation to the corporate choices within the context of Shari' $a$ ah compliant firms with exception of Hooy and Ali (2017).

Using upper echelon theory (Hambrick \& Mason, 1984) and institution-based view of a firm (Aguilera \& Jackson, 2003), this study aims at examining the relationship between board gender diversity and corporate choices pertaining to business diversification, dividend pay-out, and financial performance among Sharī'ah compliant firms. The reason for selection 
of these corporate choices is that these are fundamental choices and have been extensively studied in conventional finance research. This study is also a response to the calls for future work by recent studies (e.g. Alazzani \& Wan-Hussain, 2019; Hooy \& Ali, 2017; Hashmi, Gulzar, Khan, \& Akhtar, 2018).

We believe that the relationships will be different in Shari' ${ }^{-}$ah compliant firms as institutionbased view suggests that country-level institutions can influence corporate governance practices (e.g., female board representation) and corporate choices. Islam's consultative system promotes equality in opportunities to all and diversity ensuring representation of all segments in a society. It relates to the matter under discussion. Islam asks its followers to promote and practice equality and diversity. Allah (SWT) says, "And whoever does righteous deeds, whether male or female, while being a believer - those will enter Paradise and will not be wronged, [even as much as] the speck on a date seed" (Qur'ān, 4:124).

This shows that Islam treats everyone equally and thus any Shari'ah compliant firms shall have diverse boards. Further, there exists a broad body of knowledge that has examined the feminist perspectives in Islam (e.g. see Seedat, 2013) and argues that Islam promotes economic freedom of women. Inclusion of women on board can also be seen in that way. Thus, Shari' ${ }^{-}$ah compliant firms are expected to have gender diverse boards. Further, in line with Hooy and Ali (2017), we believe that management and governance practices of Shar' 'ah compliant firms are important in explanation of the corporate choices (business diversification, dividend pay-out and financial performance). Thus, we aim to fulfil this existing research gap by examining gender diversity on board (a governance practice) with different corporate choices in Sharī ah compliant firms.

This study contributes to the growing body of research on Islamic corporate finance and research on finance and religion in certain ways. Firstly, this study is the first attempt to establish firm-level corporate choices in context of board gender diversity in Shari'ah compliant firms. Secondly, it contributes in the stream of research exploring the insights as to how Shari'ah principles may be reflected in firm's management and governance and not just in the scope of business. Thirdly, provided that the relationship between women on board of Sharī'ah compliant firms and corporate choices is an under researched area, this study adds to the scarce empirical evidence on the said relation. Fourth, the study has comprehensively taken three corporate choices and though there is empirical evidence on the relationship of gender diversity and performance of a firm, the empirical evidence on relationship between gender diversity and business diversification and gender diversity and dividend policy remains scarce.

The next section of the paper summarizes the literature and developing the hypotheses; then methodology and estimation models along with estimation techniques employed in the study have been explained. Results and discussions along with implications, limitations and future directions are summarized at the end of the paper.

\section{LITERATURE REVIEW}

\section{Board Gender Diversity and Business Diversification in Sharī'ah compliant firms}

Diversification has long been an area of interest for strategy researchers. The central question 
in diversification decision is that whether a company should remain in one business or it may decide to expand its operations in different business lines? (Kim \& Rasheed, 2014). Board of Directors (BOD) needs to be vigilant regarding the corporate diversification initiatives as diversification can be profitable, yet risky. Managers who want to grow the business always look towards the BOD to get advice and resources (McDonald, Westphal, \& Graebner, 2008).

It has previously been established that heterogeneous boards are better for corporate strategic decision making as compared to homogenous boards. Gender diversity on boards is one way to achieve heterogeneity and hence better decision making regarding strategic choice like diversification. Presence of women on board could help the organization to assess the diversification related choices in a better way as women are known to be more considerate to others (Jaffee \& Hyde, 2000), yet are more aggressive, self-confident, daring and competitive (Neilsen \& Huse, 2010). Further, women are known to be more creative than men. Thus, it can be argued that these traits of women would enable them to think of bringing more diversification in business line.

Likewise, women perceive that power comes with knowledge and information (Triana, Miller, \& Trzebiatowski, 2014). Presence of women on board will thus increase the knowledge capability of the organization (Ruiz-Jimenez, Fuentes, \& Ruiz-Arroyo, 2014). This along with increase of diversity in thoughts with presence of women on board enhances innovation within organization (Torchia, Calabro, \& Huse, 2011). So, women on board will enhance innovative thinking and one way of innovation is diversification. So, it can be argued that gender diversity on board will have a positive relationship with the business diversification.

The same can be explained with the framework of upper echelon theory (Hambrick \& Mason, 1984) which states that corporate strategic choices are based on top management team's personal characteristics. So, the characteristics of women as stated above would make them decide to diversify in business segments. Thus, we hypothesize that

H1: Gender diversity on board is positively related with business diversification of Shari' 'ah compliant firms

\section{Board Gender Diversity and Dividend Policy in Sharī'ah Compliant Firms}

Another important strategic choice that top management of any organization has to take is dividend pay-out. Dividend policy of any firm revolves around the key decision of whether to pay dividend or not? (Ranti, 2013). Signaling theory (Ross, 1977; Spence, 1973) suggests that dividend pay-out is considered as one of the important signals to the market regarding financial health of any firm. Investors perceive dividend as an indicator of firm's performance, growth and stability (Naser, Nuseibeh, \& Rashed, 2013). Similarly, 'bird in hand' view of dividend suggests that investors prefer dividend to avoid risk and dividend helps in reduction of agency problem. Likewise, minority shareholders also see dividend as a protective shield.

Though it can be argued that dividend pay-out is more dependent on fundamentals and performance of firm. However, using upper echelon framework (Hambrick \& Mason, 1984) it can be asserted that manager's (top management team's) predispositions and their thoughts regarding dividend are also important in deciding about dividend pay-outs. Women are known 
to be more communal than men as they are more helpful, empathetic, kind, sympathetic, sensitive and mild than men (Eagly \& Carli, 2003; Neilsen \& Huse, 2010). Thus, women will be more considerate towards needs of investors especially minority shareholders and this will make heterogeneous board to decide in favour of more and consistent dividend payments as compared to homogenous board.

Female directors bring a broader perspective to board and help in better assessment of the needs of firm's diverse stakeholders (Hillman, Cannella, \& Harris, 2002). Thus, the presence of female directors makes BOD more sensitive towards communal issues (Bear, Rahman, $\&$ Post, 2010). This enables a heterogeneous board to decide in favour of more dividend pay-out. Further, as women are more risk averse than men (Borghans, Heckman, Golstyen, \& Meijers, 2009; Watson \& McNaughton, 2007; Jianakoplos \& Bernasek, 2007), they would decide to go for dividend pay-out to avoid agency conflict. Similarly, being risk averse, they would decide more in favour of risk averse investors who want dividend for their protection.

Previous research has also shown that board gender diversity has a positive relationship with cash policy (Van-Uytbergen \& Schoubben, 2015). It has been suggested that gender diversity on board can have a positive influence towards dividend pay-out (Al-Rahahleh, 2017; Pucheta-Martinez \& Bel-Oms, 2015). However, the recent evidence is still scare and is from conventional firms not religion-driven firms. Thus, based on above arguments and previous research studies, we hypothesize that

H2: Board gender diversity has positive relationship with dividend pay-out of Shari' ah compliant firms.

\section{Board Gender Diversity and Firm Performance in Sharī'ah Compliant Firms}

Financial performance of firm is the most important factor for any organization as it affects a lot of other strategic corporate decisions. Performance can be defined as the return for any organization on its investments. Researchers have argued that gender diversity helps in achievement of better business results (Herring, 2009). From perspective of agency theory (Meckling \& Jensen, 1976), gender diversity on board is an important mechanism for governance of firms (Gallego-Alvarez, Garcia-Sanchez, \& Rodriguez-Dominguez, 2010). Board gender diversity can help in reduction of agency cost (Reguera-Alvarado et al., 2015) which can actually lead to improved financial performance of a firm (Liu, Miletkov, Wei, \& Yang, 2015).

Resource Based View (RBV) of firm (Barney, 1991) suggests that firms can achieve sustainable competitive advantage via internal resources i.e. human resources. Using the framework of RBV it can be argued that diverse directors can enhance firm's value/ profits because of diversity in their unique characteristics. Prior research also suggests that board gender diversity provides a strategic resource for organizations to enhance performance of firms (Carter, Simkins, \& Simpson, 2003).

Regarding the relationship between board gender diversity and firm's performance, some researchers have reported a positive relationship (Erhardt, Werbel, \& Shrader, 2003), others have reported a negative (Bohren \& Strom, 2010), while some others have reported no relationship between the two (Du Rietz \& Henrekson, 2000). The inconclusiveness of the results 
can be attributed to the fact that different studies have been conducted in respect of different countries (Byron \& Post, 2016; Campbell \& Minguez-Vera, 2008). At the same time, these results may be dependent on the use of proxy for measuring firm's performance. In order to cater that, we have incorporated two different proxies to measure financial performance.

Despite that there is no consensus in the existing literature, recent literature suggests a positive relationship between gender diversity and firm's performance (Conyon \& He, 2017; Kilic \& Kuzey, 2016; Sanan, 2016; Zhang, 2020). We thus also expect that same relationship will hold in Shari' 'ah compliant firms. Diversity on board might serve as a positive signal for market in a way that investors would perceive organization as compliant to governance standards. Investors would place a high value to the firm that would ultimately enhance the market value of Sharī'ah compliant firms thus enhancing performance of these firms. Thus we hypothesize:

H3: Board gender diversity is positively related to financial performance in Sahriah compliant firms.

\section{METHODOLOGY}

\section{Data}

As the study involves Islamic stocks commonly termed as Shari'a ah compliant stocks, data were collected from Sharī'ah compliant stocks of Pakistan. This study used all firms in Karachi Meezan Index (KMI-30) as it is only index of the Sharī'ah compliant firms in Pakistan. The KMI, introduced in 2008, uses six different screens to classify stocks as Sharī'ah compliant. These screens include: engagement of business in "haläl" activities, maximum debt to asset ratio of $37 \%$, non-compliant investments to total assets, not more than $33 \%$, a maximum $5 \%$ of non-compliant income to total assets, illiquid assets must not be more than $25 \%$ of total assets, and finally, the net liquid asset per share must be less than the market price of share (Derigs \& Marzban, 2008). Data from all 30 firms in KMI-30 index were collected over a period of 10 years i.e. 2009-2018. The reason for using KMI-30 index is that the stocks in KMI-30 index are the most liquid Sharī'ah compliant stocks in Pakistan. All data pertaining to independent variable (Gender diversity on board) and dependent variables (dividend pay-out, business diversification and firm performance) were extracted from annual reports of the companies.

\section{Measures}

In order to measure gender diversity on the BOD, we used the number of female directors on board, as has previously been well established. In order to measure dividend pay-out, we used the numerical value of pay-out in a specific year. For firm's performance, we used two measures namely Return on Equity (ROE) and Tobin's Q. The reason for using two different measures is that while one measure uses book value, the other uses market value. So, in order to make our results more robust we used both of these measures. For business diversification, we used number of business segments a firm is operating in as a proxy. The selection of these measures is in line with Dang, Li, and Yang, (2018) and Hashmi et al. (2018). The measures employed in the study are summarized below in Table 1 . 
TABLE 1

Summary of measures

\begin{tabular}{ll}
\hline \hline Variable & Measure/Proxy \\
\hline Gender diversity on board & Number of female directors on board \\
Business diversification & Number of business segments \\
Dividend policy & Amount of dividend paid \\
Financial Performance & ROE and Tobin's Q \\
\hline \hline
\end{tabular}

\section{Estimation Models}

Given below are the estimation models used in the study:

$$
\begin{gathered}
B D_{i, t}=\beta_{0}+\beta_{1}\left(S G_{i, t}\right)+\beta_{2}\left(\operatorname{CAPEX}_{i, t}\right)+\beta_{3}\left(\operatorname{ROE}_{i, t}\right)+\beta_{4}\left(\operatorname{lnTA}_{i, t}\right)+\beta_{5}\left(B G D_{i, t}\right)+\varepsilon_{i, t} \\
\operatorname{DIVPAY}_{i, t}=\beta_{0}+\beta_{1}\left(\operatorname{lnTA}_{i, t}\right)+\beta_{2}\left(C A P E X_{i, t}\right)+\beta_{3}\left(B G D_{i, t}\right)+\varepsilon_{i, t} \\
R O E_{i, t}=\beta_{0}+\beta_{1}\left(\operatorname{lnTA}_{i, t}\right)+\beta_{2}\left(M V E_{i, t}\right)+\beta_{3}\left(\operatorname{INDDIR}_{i, t}\right)+\beta_{4}\left(B G D_{i, t}\right)+\varepsilon_{i, t} \\
T Q_{i, t}=\beta_{0}+\beta_{1}\left(\operatorname{lnTA}_{i, t}\right)+\beta_{2}\left(M V E_{i, t}\right)+\beta_{3}\left(I N D D I R_{i, t}\right)+\beta_{4}\left(B G D_{i, t}\right)+\varepsilon_{i, t}
\end{gathered}
$$

Here, $\mathrm{BD}=$ Business Diversification, $\mathrm{SG}=$ Stock Growth, $\mathrm{CAPEX}=$ Capital Expenditure, $\mathrm{ROE}=$ Return On equity, $\operatorname{lnTA}=$ natural $\log$ of total Assets, $\mathrm{BGD}=$ Board Gender Diversity, $\mathrm{MVE}=$ Market Value of Equity, TQ=Tobin's Q, INDDIR = independent directors, DIVPAY= dividend paid, =error term, $\mathrm{i}=$ cross-section, $\mathrm{t}=$ time period.

In above equations, equation-1 represents the model for hypothesis-1; equation- 2 for hypothesis- 2 while equations- 3 and 4 represent models for hypothesis-3. Control variables, as identified from literature, are also mentioned in equation for each model. We followed Mehran (1995) and Coles, Daniel, and Naveen (2006) for identification of control variables. For the relationship of board gender diversity and business diversification; stock growth, capital expenditure, performance and tangibility have been considered as control variables. For dividend pay-out, tangibility and capital expenditure whereas for performance; tangibility, firm size (market value of equity) and independent directors on board are used as control variables. Though, total assets are also used as a proxy of firm size in literature, but taking it alongside market value of equity can result in multicollinearity. However, recent studies have proposed that both these variables capture different aspects of a firm and must be treated as separate variables. For detailed discussion, see Dang et al. (2018), Hashmi et al. (2018) and Hashmi, Gulzar, Ghafoor and Naz (2020).

\section{Analysis Technique}

AS the data used in the study is panel data, so panel data regression analysis has been 
employed to test the models. Firstly, pooled OLS (POLS) regression has been applied for analysis purpose. Secondly, Hasuman test has been used to decide between fixed effect regression analysis (FEM) and random effect regression. Following the convention of reporting results, study reports both results of POLS and fixed or random effect models (whichever is appropriate as per Hausman test criteria). We also applied Generalized Methods of Moment (GMM) approach to test for likelihood of dynamic modeling, while the tests of endogenity have also been conducted.

\section{RESULTS}

\section{Descriptive Statistics and Correlation Analysis}

Descriptive statistics and correlation analysis for the study are depicted below in Table 2. The mean and standard deviation as well as correlation coefficient between the study variables are presented in the table 2. Reported descriptive statistics for dividend pay-out are of the natural log of dividend paid. It is important to note that out of 30 Shari' ${ }^{-}$ah compliant firms in data, 13 firms had no female on board of directors for the entire study period i.e. 2009-2018. That is why, the mean value of the variable is very low i.e. 0.29. In the entire dataset, highest number of female directors was 3. Likewise, for business diversification it is the number of business segments, for ROE and Tobin Q it is the exact ratio.

Correlation analysis shows that board gender diversity as measured by female directors on board is significantly and positively related with dividend pay-out $(r=0.160, p<0.05)$, business diversification $(r=0.141, p<0.05)$ and both measures of financial performance i.e. $\operatorname{ROE}(r=0.250, p<0.05)$ and Tobin's $\mathrm{Q}(r=0.151, p<0.05)$. These results provide initial support for all hypotheses of the study.

TABLE 2

Descriptive Statistics and Correlation Analysis

\begin{tabular}{llllllll}
\hline \hline & Mean & S.D. & 1 & 2 & 3 & 4 & 5 \\
\hline 1. Dividend Pay-out & 6.77 & 2.20 & 1.00 & & & & \\
2. Tobin Q & 1.33 & 2.76 & .102 & 1.00 & & & \\
3. ROE & 0.20 & 0.93 & $.365^{*}$ & $.444^{*}$ & 1.00 & & \\
4. Business diversification & 2.44 & 1.71 & .058 & -.039 & $-.125^{*}$ & 1.00 & \\
5. Board gender diversity & 0.29 & 0.64 & $.160^{*}$ & $.250^{*}$ & $.151^{*}$ & $.141^{*}$ & 1.00 \\
\hline \hline
\end{tabular}

$*=$ correlation is significant at $p<0.05$

\section{Regression Analysis}

We used panel data regression analysis for the estimation of our hypothesized models. Results of panel data estimation for model-1 are shown below in Table 3 . 
TABLE 3

Results of Panel Data Analysis for Board Gender Diversity and Business Diversification

\begin{tabular}{lll}
\hline \hline & $(1)$ & $(2)$ \\
& Pooled OLS & Fixed effect regression \\
\hline Stock growth & -0.006 & -0.002 \\
& $(0.003)$ & $(0.005)$ \\
CAPEX & $0.001^{* * *}$ & $0.001^{* *}$ \\
ROE & $(0.005)$ & $(0.000)$ \\
& 0.163 & 0.164 \\
Total Assets & $(0.117)$ & $(0.117)$ \\
& $0.172^{* * *}$ & $0.182^{* * *}$ \\
Board gender diversity & $(0.038)$ & $(0.039)$ \\
& $0.195^{* * *}$ & $0.189^{* *}$ \\
Constant & $(0.074)$ & $(0.075)$ \\
& 0.660 & 0.653 \\
Observations & $(0.538)$ & $(0.464)$ \\
Number of cross-sections & 300 & 300 \\
$R^{2}$ & 30 & 30 \\
& 0.11 & 0.12 \\
\hline & F-stat=6.81 \\
& $p$-value=0.000 \\
\hline & Result of Hausman Test \\
& Chi-sqaure=1.72 \\
& $p$-value=0.088 \\
\hline
\end{tabular}

Standard errors in parentheses

$* * * p<0.01, * * p<0.05, * p<0.1$

The results for pooled OLS regression and fixed effect regression for model- 1 of the study are shown in Table 3. Pooled OLS regression results show that board gender diversity in Sharī'ah compliant firms is significant predictor of business diversification $(\beta=0.195$, $p<0.01$ ). In order to decide between fixed and random effect regression model, Hausman test was conducted. It showed that fixed effect regression is more appropriate. Results of fixed effect regression model also show board gender diversity in Shari'‘ah compliant firms as predictor of business diversification $(\beta=0.189, p<0.01)$. The results show that the presence of female directors on board has a positive influence on diversification of business. These results support hypothesis $\mathrm{H} 1$ of the study. F-stat shows that overall model is good fit. Results for panel data estimation of model-2 are shown in Table 4.

Results of pooled OLS as depicted in table- 4 show that gender diversity on boards of Shar'̄'ah compliant firms has significant positive effect on dividend pay-out of firms ( $\beta=0.483$, $p<0.05)$. To decide between fixed and random effect regression model, Hausman test was employed. Results of Hausman test show that fixed effect regression is appropriate for this model. Fixed effect regression also shows that board gender diversity has significant positive relationship with dividend pay-out $(\beta=0.637, p<0.05)$. It implies that presence of female 
directors increases dividend pay-out of firms. This result is consistent with hypothesis H2, which is thus supported from data. Results for model-3 are shown below in Table 5.

TABLE 4

Results Of Panel Data Analysis For Board Gender Diversity And Dividend Pay-Out

\begin{tabular}{lll}
\hline \hline Dividend Pay-out & $(1)$ & $(2)$ \\
& Pooled OLS & Fixed effect regression \\
\hline Tangibility & $0.726^{* * *}$ & $0.818^{* * *}$ \\
& $(0.121)$ & $(0.131)$ \\
CAPEX & $0.00517^{* * *}$ & $0.00545^{* * *}$ \\
Board gender diversity & $(0.000985)$ & $(0.00103)$ \\
& $0.483^{* *}$ & $0.637^{* * *}$ \\
Constant & $(0.195)$ & $(0.202)$ \\
& -1.191 & -2.058 \\
Observations & $(1.312)$ & $(1.372)$ \\
Number of cross-sections & 230 & 230 \\
$R^{2}$ & 30 & 30 \\
\hline \multicolumn{5}{c}{0.210} & 0.212 \\
\hline & F-stat $=11.42$ & \\
& $p$-value $=0.000$ & \\
& Result of Hausman Test \\
& Chi-sqaure $=22.06$ & \\
\hline Standard errors in parentheses & $p$-value=0.000 \\
$* * * p<0.01, * * p<0.05, * p<0.1$ &
\end{tabular}

Results of pooled OLS regression show that board gender diversity in Sharī'ah compliant firms is significantly related to the firm performance as measured by return on equity (ROE) $(\beta=0.0365, p<0.10)$. Similarly, results of fixed effect regression also show the same $(\beta=0.0763, p<0.10)$. Though beta co-efficient are low in both cases and we are forced to use $10 \%$ significance level. However, f-test shows that overall model is good fit. These results may be attributed to the nature of proxy used to measure firm performance i.e. ROE. In order to check for robustness of these results, dynamic model estimation was thus conducted, and results have been summarized in later part of the paper. Results for model-4 are shown in Table 6.

Results for the relationship of board gender diversity and firm performance using Tobin's Q as measure of performance are shown above. Results of pooled OLS shows that board gender diversity is positively and significantly related to performance as measured by Tobin's $Q$ $(B=0.372, p<0.05)$. Results of fixed effect regression also show the same $(B=0.405, p<0.05)$. These results along with those shown in table-5 i.e. relationship between gender diversity on board and ROE, support the hypothesis H3. It must also be noted that both beta values and level of significance is better when Tobin's $Q$ is considered as proxy of performance. This also points that different measures of a same construct have different sensitivities towards 
a same area. This problem of sensitivity of measures in empirical corporate finance has been well noted now (e.g. see, Dang et al., 2018; Hashmi et al., 2018 and Hashmi et al., 2020). Further, it has also been noted previously that preference of women on board increases market value of a firm (Nguyen \& Faff, 2007). That is why, the relationship between board gender diversity and Tobin's $\mathrm{Q}$ is better as compared to ROE.

TABLE 5

Results of Panel Data Analysis for Board Gender Diversity and Performance (ROE)

\begin{tabular}{lll}
\hline \hline Dividend Pay-out & $(1)$ & $(2)$ \\
& Pooled OLS & Fixed effect regression \\
\hline Tangibility & $-0.0453^{* * *}$ & 0.00173 \\
& $(0.0121)$ & $(0.0170)$ \\
Firm Size & $3.26 \mathrm{e}-07$ & $3.17 \mathrm{e}-07$ \\
& $(2.28 \mathrm{e}-07)$ & $(2.53 \mathrm{e}-07)$ \\
Independent directors on board & 0.0194 & $0.0410^{* *}$ \\
& $(0.0138)$ & $(0.0172)$ \\
Board gender diversity & $0.0365^{*}$ & $0.0763^{*}$ \\
& $(0.0318)$ & $(0.0389)$ \\
Constant & $0.610^{* * *}$ & $0.110^{* *}$ \\
& $(0.118)$ & $(0.166)$ \\
\hline Observations & 300 & 300 \\
Number of cross-sections & 30 & 30 \\
$R^{2}$ & 0.15 & 0.22 \\
\hline \multirow{5}{*}{} & F=15.61 & \\
\hline & $p=0.000$ & \\
\hline
\end{tabular}

Standard errors in parentheses

$* * * p<0.01, * * p<0.05, * p<0.1$

\section{Robustness Check}

While dealing with panel data, one of the main problems that researchers may encounter is the issue of endogeneity. Researchers have proposed that endogeneity can be resolved by using the fixed effect regression as it controls time-invariant firm specific information (e.g. see, Dang et al., 2018). In line with this, we employed firm fixed effect regression analysis in all of our models as depicted through table-3 to Table 6 .

Similarly, it is also possible that some of the estimations might not be static, rather may be dynamic. Thus, in order to check for the robustness of our estimates we employed Generalized Method of Moments (GMM) approach. For all our models, the Arellano-Bond dynamic estimation as shown in table-7 shows that our original estimators are robust. We also employed Sargan test for testing over identifying restrictions. The results of Sargan test for all models show that our models and instruments are valid. 
TABLE 6

Results of Panel Data Analysis for Board Gender Diversity and Performance (Tobin's Q)

\begin{tabular}{lll}
\hline \hline Tobin's Q & $(1)$ & $(2)$ \\
& Pooled OLS & Fixed effect regression \\
\hline Tangibility & $-0.004^{* *}$ & $-0.005^{* *}$ \\
& $(0.002)$ & $(0.002)$ \\
Firm size & $0.353^{* *}$ & $0.840^{* *}$ \\
& $(0.120)$ & $(0.155)$ \\
Independent directors on board & 0.064 & 0.004 \\
& $(0.134)$ & $(0.157)$ \\
Board gender diversity & $0.372^{* *}$ & $0.405^{* *}$ \\
& $(0.309)$ & $(0.356)$ \\
Constant & $-1.79^{* *}$ & $-6.78^{* * *}$ \\
& $(1.18)$ & $(1.524)$ \\
\hline Observations & 300 & 300 \\
Number of cross-sections & 30 & 30 \\
$R^{2}$ & 0.18 & 0.22 \\
\hline \multirow{2}{*}{} & F=7.98 & \\
\hline & $p=0.000$ & \\
\hline
\end{tabular}

Standard errors in parentheses

$* * * p<0.01, * * p<0.05, * p<0.1$

TABLE 7

Results of Arellano \& Bond Test and Sargan Test of over Identified Restrictions

\begin{tabular}{llllllllll}
\hline \hline & \multicolumn{2}{l}{ Model-1 } & \multicolumn{2}{l}{ Model-2 } & \multicolumn{2}{c}{ Model-3 } & \multicolumn{3}{c}{ Model 4 } \\
\hline & $\frac{\beta}{\chi^{2}}$ & $p$ value & $\frac{\beta}{\chi^{2}}$ & $p$ value & $\frac{\beta}{\chi^{2}}$ & $p$ value $\frac{\beta}{x^{2}}$ & $p$ value & \\
\hline $\begin{array}{l}\text { Arellano Bond } \\
\text { test (L1) }\end{array}$ & 0.12 & 0.71 & 0.24 & 0.088 & -0.22 & 0.31 & 0.06 & 0.22 \\
$\begin{array}{l}\text { Sargan test of } \\
\text { overid. }\end{array}$ & 22.77 & 0.88 & 31.25 & 0.64 & 16.37 & 0.21 & 41.5 & 0.09 \\
Restrictions & & & & & & & & \\
\hline \hline
\end{tabular}

H0 for Arellano Bond= no autocorrelation, H0 for sargan test=over identified restrictions exists, $\beta$ is for Arellano bond estimation (L1), $\chi^{2}$ is for Sargan test.

\section{Discussion}

This study aimed to examine corporate choices of Sharī'ah compliant firms from the lens of gender diversity on the BOD of these firms. Using Upper-Echelon theory (Hambrick \& Mason, 1984) and arguments presented by Hooy and Ali (2017) regarding Sharī'ah compliant firms, we hypothesized that gender diversity on board of Sharī'ah compliant firms would enhance business diversification, dividend pay-out and financial performance of these firms. 
Our results support the formulated hypotheses. These results will be discussed below, in light of the theory.

First hypothesis of the study was that board gender diversity has positive relationship with business diversification of Sharí'ah compliant firms. Results support this hypothesis. Literature shows that women tends to be risk averse than men (Borghans et al., 2009; Jianakoplos \& Bernasek, 2007; Watson \& McNaughton, 2007). It is also well established that gender diversity on board decreases corporate risk raking (Loukil \& Yousfi, 2015). It is also shown in previous research that corporate risk decreases with business diversification. Thus, when board is more diversified, there are more chances of business diversification as women directors might use it as a tool to diversify risk. Upper-Echelon framework also indicates that corporate decisions are dependent on personal traits of top management team. Risk aversion trait of women as directors can lead to enhanced diversification of business operations.

Second hypothesis of the study was that board gender diversity has a positive relationship with dividend pay-out of the Sharí ${ }^{-}$ah compliant firms. Women are known to be more sensitive than men. They are also considered as more human oriented and considerate towards feelings of others (Bear et al., 2010). This trait of women directors would make them considerate towards shareholders too, specifically towards minority shareholders (generally termed as orphans and widows). Dividend pay-out is a good way to protect them and women directors on board of Shari' 'ah compliant firms would thus tend to pay more dividend. Further, as women are risk averse, diverse boards are likely to induce in more dividend payments in order to avoid agency conflict too. Our results are in line with the previous research which shows that gender diversity on board leads to high dividend payments (Al-Rahahleh, 2017; Pucheta-Martinez \& Bel-Oms, 2015).

Third hypothesis of the study was related to relationship of board gender diversity with another important corporate choice i.e. financial performance. Our formulated hypothesis was that board gender diversity enhances financial performance of firms which has been supported by our results too. Our result is in line with the extant research that supports the same view between the two variables (e.g. see, Chalres, Dang, \& Redor, 2018; Conyon \& He, 2017; Kilic \& Kuzey, 2016; Sanan, 2016; Zhang, 2020). Previously Alazzani et al. (2017) have also noted that gender diversity on board leads to better financial performance in Islamic stocks/ Muslim countries. Board diversity brings diverse opinions on board, while diverse decision making helps in achieving better financial performance. We used two different measures of financial performance, namely ROE and Tobin's Q. While our results for both, as shown in model-3 and model-4 of study are supported, results for using Tobin's Q as measure of performance are better.

\section{CONCLUSION}

This study was conducted with the aim to enhance the existing body of knowledge of Islamic corporate finance. It examined the relationship between board gender diversity and corporate choices of Sharī'ah compliant firms. The results show that gender diverse boards result in better dividend pay-out, financial performance and business diversification. Overall, these results carry important implications for managers and policy makers of Sharī ah compliant 
firms and the regulators. Managers and policy makers of Sharī'ah compliant firms must device such policies that ensure presence of female directors on board. Female directors bring diversity of thoughts and could help in ending monotony in decision making. Our results show that gender diversity on boards is beneficial for both management and shareholders of firm. As presence of female directors on board enhances firm's performance as well as dividend pay-out, so diverse boards are beneficial for the management of the Shari' ah compliant firms as their salaries and incentives are based on performance, and also for shareholders who may get higher dividends.

Government and the regulator should take measures to ensure that firms shall induct more females to their BODs. Government may come up with legislations like those in many other non-Muslim countries that make it mandatory for organizations to have a specific percentage of female directors on board. Despite of growing trend of inducting females in board worldwide, the situation is not good in Pakistan. Women on Boards Report (2018) reveals that only $3.99 \%$ of directors of PSX-100 index companies are female. The situation is even bad in case of Sharī'ah compliant firms for which our data shows that 13 out of 30 companies had no female board member in last 10 years and the maximum number ever for any company has been 3 directors. Our results thus serve as evidence that the female directors on board bring efficiency which results in better decision making. By doing so, we may also be contributing towards a greater universal objective of women empowerment, as stated in United Nations Sustainable Development Goals (UNSDGs) No. 5.

Like every study, our study has some limitations too. These include: use of data from stocks of one Islamic index only and use of only three corporate choices. For generalization of results, future researchers may conduct studies using data from different Muslim countries and other indices of Sharī'ah compliant firms. Another important study can be conducted by comparing the results of Sharī'ah and non-Sharī'ah compliant firms operating in Muslim countries to see whether the relationship between gender diversity on boards and corporate choices is uniform or not. Future researchers can also enhance this work by examining gender diversity on board in relation to other corporate choices like managerial incentives and compensations. There can be another important dimension to investigate corporate choices of both Sharī'ah and non-Shari' ${ }^{-}$ah compliant firms and that is gender diversity in top management team. It would be worthy to note whether gender diversity in top management team including CEO and senior managers, hold same results with corporate choices i.e. results in better corporate choices or not.

\section{REFERENCES}

Alazzani, A., Hassanein, A., \& Aljanadi, Y. (2017), Impact of gender diversity on social and environmental performance: Evidence from Malaysia, Corporate Governance: The International Journal of Business in Society, 17(2),266-283. doi: https://doi.org/10.1108/CG12-2015-0161

Alazzani, A., Wan-Hussin, W. N., \& Jones, M. (2019). Muslim CEO, women on boards and corporate responsibility reporting: Some evidence from Malaysia. Journal of Islamic Accounting and Business Research, 10(2), 274-296. doi: https://doi.org/10.1108/JIABR- 


\section{1-2017-0002}

Al-Rahahleh, A. S. (2017). Corporate governance quality, board gender diversity and corporate dividend policy: Evidence from Jordan. Australasian Accounting, Business and Finance Journal, 11(2), 86-104. doi: https://doi.org/10.14453/aabfj.v11i2.6

Aguilera, R. V., \& Jackson, G. (2003). The cross-national diversity of corporate governance: Dimensions and determinants. Academy of Management Review, 28(3), 447-465. doi: https://doi.org/10.5465/amr.2003.10196772

Barney, J. (1991). Firm resources and sustained competitive advantage. Journal of Management, 17(1), 99-120. doi: https://doi.org/10.1177/014920639101700108

Bear, S., Rahman, N., \& Post, C. (2010). The impact of board diversity and gender composition on corporate social responsibility and firm reputation, Journal of Business Ethics, 97(2), 207-221. doi: https://doi.org/10.1007/s10551-010-0505-2

Bernile, G., Bhagwat, V., \& Rau, P. R. (2017). What doesn't kill you will only make you more risk-loving: Early-life disasters and CEO behavior. The Journal of Finance, 72(1), 167-206. doi: https://doi.org/10.1111/jofi.12432

Bohren, O., \& Strom, R. O. (2010). Governance and politics: Regulating independence and diversity in the board room. Journal of Business Finance $\mathcal{E}$ Accounting, 37(9-10), 1281-1308. doi: https://doi.org/10.1111/j.1468-5957.2010.02222.x

Borghans, L., Heckman, J. J., Golsteyn, B. H., \& Meijers, H. (2009). Gender differences in risk aversion and ambiguity aversion. Journal of the European Economic Association, 7(2-3), 649-658. doi: https://doi.org/10.1162/JEEA.2009.7.2-3.649

Byron, K., \& Post, C. (2016). Women on boards of directors and corporate social performance: A meta-analysis. Corporate Governance: An International Review, 24(4), 428-442. doi: https://doi.org/10.1111/corg.12165

Campbell, K., \& Minguez-Vera, A. (2008), Gender diversity in the boardroom and firm financial performance. Journal of Business Ethics, 83(3), 435-451.

doi: https://doi.org/10.1007/s10551-007-9630-y

Carter, D., Simkins, B. J., \& Simpson, W.G. (2003). Corporate governance, board diversity, and firm value. The Financial Review, 38(1), 33-53.

doi: https://doi.org/10.1111/1540-6288.00034 Coles, J., Daniel, N., \& Naveen, L. (2006). Managerial incentives and risk-taking. Journal of Financial Economics, 79, 431-468. doi: https://doi.org/10.1016/j.jfineco.2004.09.004

Conyon, M. J., \& He, L. (2017). Firm performance and boardroom gender diversity: A quantile regression approach. Journal of Business Research, 79, 198-211. doi: https://doi.org/10.1016/j.jbusres.2017.02.006

Dang, C., Li, Z. F., \& Yang, C. (2018). Measuring firm size in empirical corporate finance. Journal of Banking \& Finance, 86, 159-176. doi: https://doi.org/10.1016/j.jbankfin.2017.09.006

Derigs, U., \& Marzban, S. (2008). Review and analysis of current Sharī'ah compliant equity screening practices. International Journal of Islamic and Middle Eastern Finance and Management, 1(4). 285-303. doi: https://doi.org/10.1108/17538390810919600 
Du Rietz, A., \& Henrekson, M. (2000). Testing the female underperformance hypothesis. Small Business Economics, 14(1), 1-10. doi: https://doi.org/10.1023/A:1008106215480 Eagly, A. H., \& Carli, L. L. (2003). The female leadership advantage: An evaluation of the evidence. The Leadership Quarterly, 14(6), 807-834. doi: https://doi.org/10.1016/j.leaqua.2003.09.004

Erhardt, N., Werbel, J., \& Shrader, C. (2003), Board of director diversity and firm financial performance. Corporate Governance, 11(2),102-111. doi: https://doi.org/10.1111/14678683.00011

Galbreath, J. (2011). Are there gender-related influences on corporate sustainability? A study of women on boards of directors. Journal of Management $\mathcal{E}$ Organization, 17(1), 17-38. doi: https://doi.org/10.1017/S1833367200001693

Gallego-Alvarez, I., Garcia-Sanchez, I. M., \& Rodriguez-Dominguez, L. (2010). The influence of gender diversity on corporate performance. Revista de Contabilidad-Spanish Accounting Review, 13(1), 53-88.

doi: ttps://doi.org/10.1016/S1138-4891(10)70012-1

Gul, F. A., Srinidhi, B., \& Ng, A. C. (2011). Does board gender diversity improve the informativeness of stock prices?. Journal of Accounting and Economics, 51(3), 314-338. doi: https://doi.org/10.1016/j.jacceco.2011.01.005

Hambrick, D. C., \& Mason, P. A. (1984). Upper echelons: The organization as a reflection of its top managers. Academy of Management Review, 9(2), 193-206. doi: https://doi.org/10.5465/amr.1984.4277628

Hashmi, S. D., Gulzar, S., Khan, M. J., \& Akhtar, M. (2018). Sensitivity of firm size measures to practices of corporate finance: Evidence from Sharı`‘ah compliant firms. Journal of Islamic Business $\mathcal{E}$ Management, 8(2), 538-558. doi: https://doi.org/10.26501/jibm/2018.0802-012

Hashmi, S.D., Gulzar S., Ghafoor, Z. G., \& Naz, I. (2020). Sensitivity of firm size measures to practices of corporate finance: Evidence from BRICS. Future Business Journal, 6(9), 2-19. doi: https://doi.org/10.1186/s43093-020-00015-y

Herring, C. (2009). Does diversity pay?: Race, gender, and the business case for diversity. American Sociological Review, 74(2), 208-224.

doi: https://doi.org/10.1177/000312240907400203

Hillman, A. J., Cannella J. A. A., \& Harris, I. C. (2002). Women and racial minorities in the boardroom: How do directors differ?. Journal of Management, 28(6), 747-763. doi: ps://doi.org/10.1177/014920630202800603

Hooy, C. W., \& Ali, R. (2017). Does a Muslim CEO matter in Sharī'ah-compliant companies? Evidence from Malaysia. Pacific-Basin Finance Journal, 42, 126-141. doi: https://doi.org/10.1016/j.pacfin.2016.08.010

Jaffee, S., \& Hyde, J. S. (2000). Gender differences in moral orientation: a meta-analysis. Psychological Bulletin, 126(5), 703-726.

doi: https://doi.org/10.1037/0033-2909.126.5.703

Jianakoplos, N. A., \& Bernasek, A. (1998). Are women more risk averse?. Economic Inquiry, 36(4), 620-630. doi: https://doi.org/10.1111/j.1465-7295.1998.tb01740.x 
Kilic, M., \& Kuzey, C. (2016). The effect of board gender diversity on firm performance: evidence from Turkey. Gender in Management: An International Journal, 31(7). 434455. doi: https://doi.org/10.1108/GM-10-2015-0088

Kim, K. H., \& Rasheed, A. A. (2014). Board heterogeneity, corporate diversification and firm performance. Journal of Management Research, 14(2), 121-139.

Liu, Y., Miletkov, M. K., Wei, Z., \& Yang, T. (2015). Board independence and firm performance in China. Journal of Corporate Finance, 30, 223-244. doi: https://doi.org/10.1016/j.jcorpfin.2014.12.004

Loukil, N., \& Yousfi, O. (2016). Does gender diversity on corporate boards increase risktaking?. Canadian Journal of Administrative Sciences/Revue Canadienne des Sciences de l'Administration, 33(1), 66-81. doi: https://doi.org/10.1002/cjas.1326

McDonald, M. L., Westphal, J. D., \& Graebner, M. E. (2008). What do they know? The effects of outside director acquisition experience on firm acquisition performance. Strategic Management Journal, 29(11), 1155-1177. doi: https://doi.org/10.1002/smj.704 Meckling, W. H., \& Jensen, M. C. (1976). Theory of the firm: Managerial behavior, agency costs and ownership structure. Journal of Financial Economics, 3(4), 305-360. doi: https://doi.org/10.1016/0304-405X(76)90026-X

Mehran, H. (1995). Executive compensation structure, ownership, and firm performance. Journal of Financial Economics, 38, 163-184. doi: https://doi.org/10.1016/0304405X(94)00809-F

Naser, K., Nuseibeh, R., \& Rashed, W. (2013). Managers' perception of dividend policy: Evidence from companies listed on Abu Dhabi Securities Exchange. Issues in Business Management and Economics, 1(1), 1-12.

Nielsen, S., \& Huse, M. (2010). Women directors' contribution to board decision-making and strategic involvement: The role of equality perception. European Management Review, 7(1), 16-29. doi: https://doi.org/10.1057/emr.2009.27

Nguyen, H., \& Faff, R. (2007). Impact of board size and board diversity on firm value: Australian evidence. Corporate Ownership and Control, 4(2), 24-32. doi: https://doi.org/10.22495/cocv4i2p2

Parola, H.R., Ellis, K.M., \& Golden, P. (2015), Performance effects of top management team gender diversity during the merger and acquisition process. Management Decision, 53(1), 57-74. doi: https://doi.org/10.1108/MD-03-2014-0141

Post, C., \& Byron, K. (2015). Women on boards and firm financial performance: A metaanalysis. Academy of Management Journal, 58(5), 1546-1571.

doi: https://doi.org/10.5465/amj.2013.0319

Pucheta-Martinez, M. C., \& Bel-Oms, I. (2016). The board of directors and dividend policy: The effect of gender diversity. Industrial and Corporate Change, 25(3), 523-547. doi: https://doi.org/10.1093/icc/dtv040

Ranti, U. O. (2013). Determinants of dividend policy: A study of selected listed Firms in Nigeria. Manager, 17, 107-119.

Reguera-Alvarado, N., de Fuentes, P., \& Laffarga, J. (2017). Does board gender diversity influence financial performance? Evidence from Spain. Journal of Business Ethics, 141(2), 337-350. doi: https://doi.org/10.1007/s10551-015-2735-9 
Rao, K., \& Tilt, C. (2016), Board composition and corporate social responsibility: The role of diversity, gender, strategy and decision making, Journal of Business Ethics, 138(2), 327-347. doi: https://doi.org/10.1007/s10551-015-2613-5

Ross, S. A. (1977). The determination of financial structure: The incentive signaling structure. Bell Journal of Economics, 8, 23-40. doi: https://doi.org/10.2307/3003485

Ruiz-Jimenez, J. M., Del Mar Fuentes-Fuentes, M., \& Ruiz-Arroyo, M. (2016). Knowledge combination capability and innovation: The effects of gender diversity on top management teams in technology-based firms. Journal of Business Ethics, 135(3), 503-515. doi: https://doi.org/10.1007/s10551-014-2462-7

Sanan, N. K. (2016). Board gender diversity and firm performance: evidence from India. Asian Journal of Business Ethics, 5(1-2), 1-18. doi: https://doi.org/10.1007/s13520-0160050-X

Seedat, F. (2013). Islam, feminism, and Islamic feminism: Between inadequacy and inevitability. Journal of Feminist Studies in Religion, 29(2), 25-45. doi: https://doi.org/10.2979/jfemistudreli.29.2.25

Shaukat, A., Qiu, Y., \& Trojanowski, G. (2016). Board attributes, corporate social responsibility strategy, and corporate environmental and social performance. Journal of Business Ethics, 135(3), 569-585. doi: https://doi.org/10.1007/s10551-014-2460-9

Siciliano, J. (1996), The relationship of board member diversity to organizational performance. Journal of Business Ethics, 15(12), 1313-1320.

doi: https://doi.org/10.1007/BF00411816

Spence, M. 1973. Job market signaling. Quarterly Journal of Economics, 87, 355-374. doi: https://doi.org/10.2307/1882010

Torchia, M., Calabro, A., \& Huse, M. (2011). Women directors on corporate boards: From tokenism to critical mass. Journal of Business Ethics, 102(2), 299-317. doi: https://doi.org/10.1007/s10551-011-0815-z

Triana, M. D. C., Miller, T. L., \& Trzebiatowski, T. M. (2014). The double-edged nature of board gender diversity: Diversity, firm performance, and the power of women directors as predictors of strategic change. Organization Science, 25(2), 609-632. doi: https://doi.org/10.1287/orsc.2013.0842

Van Uytbergen, S.,\& Schoubben, F. (2015). The effect of gender diversity on corporate cash policy. Paper presented at the Annual Conference European Financial Management, Amsterdam, The Netherlands.

Watson, J., \& McNaughton, M. (2007). Gender differences in risk aversion and expected retirement benefits. Financial Analysts Journal, 63(4), 52-62.

doi: https://doi.org/10.2469/faj.v63.n4.4749

Women on Boards Report (2018). Retrieved from: http://safe-asia.com/

Zhang, L. (2020). An institutional approach to board gender diversity and firm performance.

Organization Science, 31(2), 439-457. doi: https://doi.org/10.1287/orsc.2019.1297 